\title{
Effects of Intermittent Hypoglycaemia in Pregnant Rats on the Functional Development of the Pancreatic B-Cells of Their Offspring
}

\author{
F. Sodoyez-Goffaux and J.-C. Sodoyez \\ Dept. of Pediatrics and Dept. of Internal Medicine, Univ. of Liège, Liège, Belgium
}

\begin{abstract}
Summary. Intermittent hypoglycaemia was induced by insulin injections into pregnant rats. At birth, the pups body weight and pancreatic insulin content were slightly but significantly decreased. In contrast, the $\mathrm{B}$-cells of these newborn rats responded more markedly to a glucose challenge than the controls. The pancreases of the insulin injected rats were grearly depleted of insulin, possibly because of feedback inhibition of insulin synthesis by exogenous insulin. This inhibitory effect was restricted to the mother since the injected insulin did not cross the placental barrier. It is proposed that the nutrient supply to the fetus influenced body growth and pancreatic insulin accumulation whereas blood glucose variations, even intermittent hypoglycaemia, promoted precocious maturation of the B-cell glucoreceptor system.
\end{abstract}

Key words: Pregnancy, rats, insulin treatment, hypoglycaemia, neonatal rats, pancreas, insulin release, B-cell activity, glucoreceptors.

In all species studied so far, the fetal B-cells are able to synthesize insulin before they become able to regulate hormone secretion.

For instance, in the rat insulin is detectable around the 11th day of gestation [1], whereas maturation of the secretory mechanisms occurs on the 1st or, at the latest, on the 2 nd day of extrauterine life $[2,3]$. The time-lag between the appearance of the ability to synthesize insulin and to regulate the secretion of the hormone suggests that, at least in part, these two functions of the B-cells are independent of each other.

In man a few conditions are known or supposed to alter maturation of the fetal B-cells. In particular, maternal diabetes is known to induce islet hyperplasia [4] with increased number of B-cells [5]. These mor- phologic changes are associated with increased pancreatic insulin content $[6,7]$ and early maturation of the insulin secretion mechanisms [8]. Numerous experimental data support the hypothesis that high glucose concentration favors B-cell growth and insulin synthesis in the fetal pancreatic gland $[9,10]$. Recently, it has been demonstrated that a daily two hour glucose infusion during the last 5 days of gestation was sufficient to induce prematurely the rat fetal B-cell reactivity to a glucose challenge [11]. The author concluded that maternal hyperglycaemia was responsible for precocious fetal B-cell maturation.

These experiments, however, do not allow discrimination between blood glucose variation and increased average blood glucose as inducers of B-cell reactivity to glucose. To test the relative importance of these two factors, pregnant rats were rendered intermittently hypoglycaemic with insulin injections and the insulin output of the pancreas of their offspring was studied in vitro.

\section{Materials and Methods}

Virgin or pregnant albino rats were caged individually and had free access to food and water. A group of pregnant rats were injected subcutaneously with ultralente insulin, $10 \mathrm{U} / \mathrm{kg} /$ day, from the 10 th to the 22nd day of gestation. The weight gain (body weight immediately after delivery minus weight on mating day) was $40 \mathrm{~g}$ and $38 \mathrm{~g}$ in the insulin-treated and the non-treated rats respectively. Three to $15 \mathrm{hrs}$ after spontaneous delivery (average $8 \mathrm{hrs}$ ), the rat pups were weighed and killed by decapitation. The pancreatic glands of the pups were quickly removed, weighed and preincubated at $37^{\circ}$ in a Krebs-Ringer Bicarbonate buffer enriched with $1 \mathrm{~g} / 100 \mathrm{ml}$ bovine serum albumin (crystallized and lyophilized, Sigma 
Chemical Co.) and $50 \mathrm{mg} / 100 \mathrm{ml}$ D-glucose under a $95 \% \mathrm{O}_{2} 5 \% \mathrm{CO}_{2}$ atmosphere. After a 30 min preincubation, the pancreases were transferred to Erlenmeyer flasks containing $2.5 \mathrm{ml}$ of Krebs-Ringer Bicarbonate buffer enriched with $1 \mathrm{~g} / 100 \mathrm{ml}$ bovine serum albumin and 50 or $300 \mathrm{mg} / 100 \mathrm{ml} \mathrm{D}$-glucose and incubated for $1 \mathrm{hr}$ at $37^{\circ}$ under a $95 \% \mathrm{O}_{2} 5 \% \mathrm{CO}_{2}$ atmosphere. At the end of the incubation, the medium

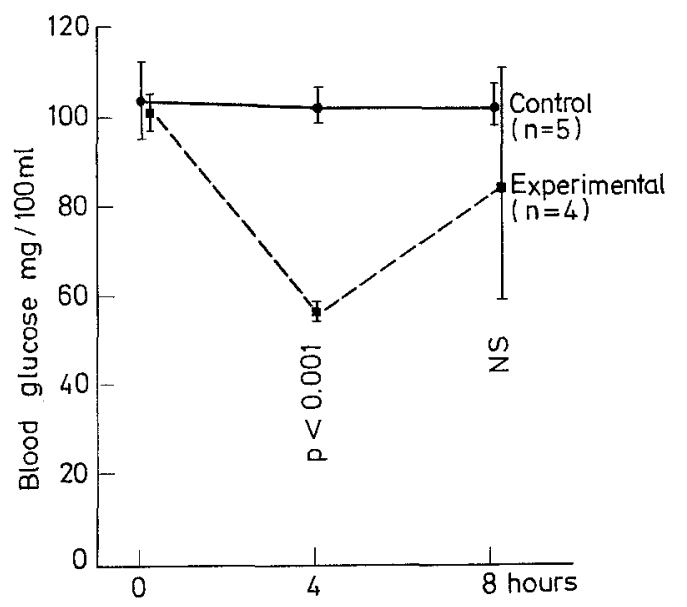

Fig. 1. Blood glucose concentration following injection of $10 \mathrm{U} / \mathrm{kg}$ of ultralente insulin (Experimental, $\mathrm{n}=4$ ) or an equivalent volume of saline (Control, $\mathrm{n}=5$ ) into pregnant rats, 14 days after mating. Average $\pm 1 \mathrm{SD}$

Table 1. Pancreatic insulin content of saline or insulin injected rats. $\mathrm{U}$ /pancreas, average $\pm \mathrm{SD}$, number of animals in parentheses

\begin{tabular}{llll}
\hline & Saline injected & Insulin injected & $\begin{array}{l}\mathrm{P} \\
\text { Horizontal } \\
\text { comparison }\end{array}$ \\
\hline Virgin & $3,05 \pm 0,37$ & $1,73 \pm 0,21$ & $<0,001$ \\
At delivery & $(7)$ & $(3)$ & $<0,001$ \\
& $3,31 \pm 0,34$ & $1,71 \pm 0,41$ & \\
P & $(7)$ & $(7)$ & \\
Vertical & $>0,05$ & $>0,05$ & \\
comparison & & & \\
\hline
\end{tabular}

Table 2. Effect of intermittent maternal hyperinsulinism on the rate of body growth and of insulin accumulation in the pancreas of their offspring mean $\pm \mathrm{SD}$

\begin{tabular}{|c|c|c|c|}
\hline & $\begin{array}{l}\text { Control } \\
\mathrm{n}=69\end{array}$ & $\begin{array}{l}\text { Experimental } \\
\mathbf{n}=73\end{array}$ & $\mathbf{P}$ \\
\hline Body weight, $g$ & $6,40 \pm 0,45$ & $6,12 \pm 0,51$ & $<0,001$ \\
\hline $\begin{array}{l}\text { Pancreatic gland } \\
\text { weight, } \mathrm{mg}\end{array}$ & $32,6 \pm 3,2$ & $30 \pm 3,8$ & $<0,001$ \\
\hline $\begin{array}{l}\text { Pancreatic insulin } \\
\text { content, } \mathrm{mU}\end{array}$ & $131,1 \pm 21,2$ & $106,2 \pm 17,8$ & $<0,001$ \\
\hline $\begin{array}{l}\text { Pancreatic insulin } \\
\text { concentration, } \mathrm{mU} / \mathrm{mg}\end{array}$ & $\mathrm{g}^{4,03 \pm 0,48}$ & $3,56 \pm 0,50$ & $<0,001$ \\
\hline
\end{tabular}

was frozen quickly at $-25^{\circ}$, and each pancreatic gland was ground in a glass homogenizer containing $2 \mathrm{ml}$ of acid-ethanol. The pancreas of the mother was also removed, weighed and extracted in $20 \mathrm{ml}$ acidethanol.

After 24 hrs at $4^{\circ}$, the acid-ethanol extracts were centrifuged and the clear supernatant stored at $-25^{\circ}$.

Insulin assay was performed on appropriate dilutions $(1 / 10$ for incubation medium, $1 / 1000$ for rat pups pancreatic extract, $1 / 5000$ for adult rat pancreatic extract) using the double-antibody radioimmunoassay method of Hales and Randle [12]. All values are given as human insulin equivalents since the standard and the labelled hormone were of human origin.

On the 14th day of gestation, under light ether anesthesia, $0.1 \mathrm{ml}$ blood samples were taken from the orbital sinus $24 \mathrm{hrs}$ after the previous insulin or saline injection and immediately before (time 0 ), 4 and $8 \mathrm{hrs}$ after a new injection. Maternal blood glucose concentration was determined using the hexokinase method [13].

\section{Results}

At the dose of $10 \mathrm{U} / \mathrm{kg} /$ day, ultralente insulin killed approximately $20 \%$ of the pregnant rats, either shortly after the beginning of the injection program or at the end of gestation. A higher insulin dosage, in one $(15 \mathrm{U} / \mathrm{kg})$ or two $(7,5 \mathrm{U} / \mathrm{kg})$ daily injections, was found to be above the L. D. 50. Exogenous insulin had no obvious effect on the duration of gestation, the litter size, nor the percentage of malformed or stillborn pups.

As shown in Fig. 1, blood glucose concentration was significantly decreased $4 \mathrm{hrs}$ after the $10 \mathrm{U} / \mathrm{kg}$ insulin injection. The hypoglycaemic effect was no longer statistically significant after $8 \mathrm{hrs}$. Twenty-four hours after the injection, the experimental and control animals had identical blood glucose concentrations. In contrast to that of the insulin injected rats, the blood glucose concentration profile was remarkably constant in the control group.

In addition to inducing intermittent hypoglycaemia, repeated insulin injections markedly inhibited endogenous hormone synthesis in the pancreas of the mother. As shown in Table 1, the pancreatic insulin content at delivery was reduced by approximately $50 \%$ in the experimental animals.

It can be seen in Table 2, that the body and pancreas weights of the experimental pups were slightly but significantly decreased. Pancreatic insulin content and concentration were also decreased, but to a much lesser extent than their mothers'.

The pancreatic insulin release of 73 experimental 
and 69 control pups was studied in vitro and the results are summarized in Table 3. In the presence of low glucose concentration, the pancreases of the offspring of insulin injected rats released significantly less insulin than those of control pups. When the pancreatic glands were incubated at the higher glucose concentration, insulin output was enhanced only in the offspring of insulin injected rats, the increment over basal release being $84 \%(p<0,01)$ in the experimental group and $23 \%(\mathrm{p}>0.05)$ in the controls.

To minimize the effect of litter size on calculations,

Table 3. Insulin release of the pancreases of newborn rats of saline (control) or insulin injected (experimental) mothers. IRI, $\mu U /$ pancreas $/ \mathrm{hr}$ mean $\pm \mathrm{SD}$, number of offspring in parentheses

\begin{tabular}{llll}
\hline & $\begin{array}{l}\text { Glucose } \\
50 \mathrm{mg} / 100 \mathrm{ml}\end{array}$ & $\begin{array}{l}\text { Glucose } \\
300 \mathrm{mg} / 100 \mathrm{ml}\end{array}$ & $\begin{array}{l}\mathrm{P} \\
\text { Horizontal } \\
\text { comparison }\end{array}$ \\
\hline Control & $509,3 \pm 265,7$ & $626,8 \pm 262,7$ & $>0,05$ \\
& $(35)$ & $(34)$ & \\
Experimental & $266,9 \pm 176,4$ & $490,2 \pm 434,1<0,01$ \\
$\mathrm{P}$ & $(37)$ & $(36)$ & \\
Vertical & $<0,001$ & $>0,1$ & \\
comparison & & & \\
\hline
\end{tabular}

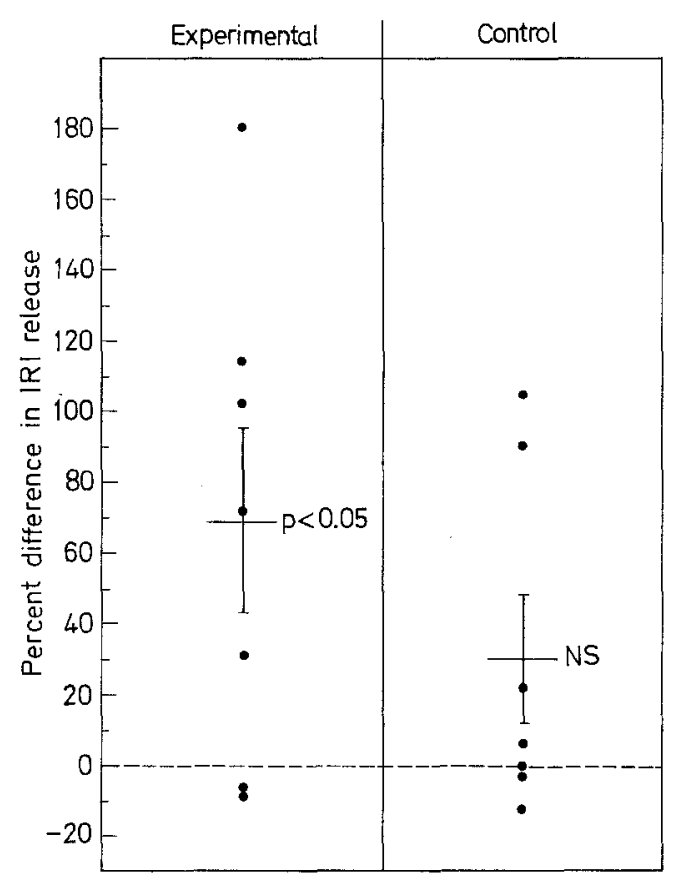

Fig. 2. Newborn rat B-cell reactivity to glucose studied in litters of saline injected (Control, $\mathrm{n}=7$ ) and insulin injected (Experimental, $\mathrm{n}=7$ ) rats. Each point represents the average increase of insulin output per litter in the presence of high glucose concentration, expressed as percent of basal release. The mean increment (horizontal bar, \pm SEM) was statistically different from zero only in the experimental group the results were also expressed as average increase of insulin secretion per litter (Fig. 2). Using this mode of computation, B-cell reactivity to glucose averaged $69 \%(\mathrm{p}<0.05)$ in the 7 experimental litters and $29.5 \%$ (NS) in the 7 control ones.

\section{Discussion}

The feeding habits of rats are different from those of man. Instead of eating 3 meals per day, rats almost constantly nibble. Consequently, the blood glucose profile of rats having free access to food is fairly flat, and devoid of postprandial peaks. Insulin injections decreased the average blood glucose and caused variations in the circadian blood glucose profile. Fetal blood glucose concentration has been shown to be a fraction of maternal blood glucose and to be parallel to it until the last few days of gestation, at which time the fetus begins to be able to regulate its own blood glucose concentration [14]. Therefore, in our experiments we have assumed that maternal insulin injections produced fetal hypoglycaemia between the 10th and the 20th days of gestation while, during the last 2 days, fetal hypoglycaemia may have been partially or totally damped.

Intermittent maternal hyperinsulinism reduces the fetal supply of glucose and probably of other nutrients such as free fatty acids and some aminoacids. Intermittent fetal "starvation" probably accounts for the reduction in the pups body weight, pancreatic weight and pancreatic insulin content.

Despite this decrease in insulin content, the B-cells of the pups of insulin injected mothers reacted earlier to a glucose challenge than the B-cells of control pups, suggesting that maturation of the glucoreceptor system may have been accelerated by blood glucose fluctuations even though the average blood glucose was decreased. If our hypothesis is correct, precocious B-cell maturation in infants of diabetic mothers would be, at least in part, due to wide blood glucose variations. Conversely flat maternal blood glucose profile, present throughout pregnancy, might be expected to delay maturation of the fetal insulin secretory mechanism. This concept has been postulated by Gerrard and Chin [15] to explain the pathogenesis of transient diabetes mellitus in the newborn. Since their original observation, several mothers whose infants suffered from neonatal diabetes were subsequently shown to have a flat oral glucose tolerance test $[16,17]$.

We are tempted to speculate that the magnitude of the average glucose and/or other nutrient supply mainly influences the total number of B-cells. Frye [18] showed that the mitotic index of B-cells was 
increased in rat pups of alloxan diabetic mothers and decreased in the offspring of insulin injected rats.

It must be noted that the pancreatic insulin content of the insulin injected mothers was reduced by $48 \%$ whereas the B-cells of their offspring were able to accumulate almost as much insulin as the control pups. This decreased maternal pancreatic insulin content probably reflects feedback inhibition of insulin synthesis by exogenous insulin [19-22], this effect being restricted to the mother since the hormone does not cross the feto-placental barrier [23-26].

In conclusion, our experiments suggest that a decrease in average blood glucose concentration in the mother slows down the rate of body growth of the offspring and the insulin accumulation in their pancreas. Intermittent hypoglycaemia on the other hand, promoted precocious maturation of the mechanism regulating insulin secretion in response to a glucose challenge. Our experimental design did not allow speculation on the mechanism whereby intermittent hypoglycaemia affected the rate of B-cell maturation, nor a comparison of the mode of action of intermittent maternal hyper- and hypoglycaemia.

Acknowledgement. The excellent technical assistance of Miss $\mathrm{Cl}$. Devos is gratefully aknowledged.

\section{References}

1. Clarck, W. R., Rutter, W. J.: Synthesis and accumulation of insulin in the fetal rat pancreas. Develop. Biol. 29, 468-481 (1972)

2. Asplund, K., Westman, S., Hellerström, C.: Glucose stimulation of insulin secretion from the isolated pancreas of foetal and newborn rats. Diabetologia 5, 260-262 (1969)

3. Sodoyez-Goffaux, F., Sodoyez, J.-C., Foà, P. P.: Effects of gestational age, birth and feeding on the insulinogenic response to glucose and tolbutamide by fetal and newborn rat pancreas. Diabetes 20, 586-591 (1971)

4. Dubreuil, G., Anderodias, J.: Ilots de Langerhans géants chez un nouveau-né issu de mère glucosurique. C. R. Soc. Biol. (Paris) 23, 1490-1493 (1920)

5. Cardell, B. S.: Hypertrophy and hyperplasia of the pancreatic islets in newborn infants. J. Path. Bact. 66, 335-346 (1953)

6. Steinke, J., Driscoll, S. G.: The extractable insulin content of pancreas from fetuses and infants of diabetic and control mothers. Diabetes 14, 573-578 (1965)

7. De Gasparo, M., Van Assche, A., Gepts, W., Hoet, J. J.: The histology of the endocrine pancreas and the insulin content in the microdissected islets of foetal pancreas. Rev. franç. Étud. clin. biol. 14, 904-906 (1969)

8. Baird, J. D., Farquhar, J. W.: The insulin secreting capacity of the pancreas in newborn infants of normal and diabetic women. Lancet 1962 I, 71-74

9. Kim, J. N.: Effects of hyperglycemia on beta granulations in pancreatic islets of fetuses from diabetic rats. Diabetes 14, 137-141 (1965)
10. Vecchio, D., Gonet, A. E.: Culture d'organe de pancreas foetal de rat: I. Effects du glucose, d'autres composants du milieu de culture et d'un sulfamidé hypoglycémiant. Helv. physiol. pharmacol. Acta 25, 103-122 (1967)

11. Asplund, K.: Effect of intermittent glucose infusions in pregnant rats on the functional development of the foetal pancreatic B-cells. J. Endocr. 59, 285-293 (1973)

12. Hales, C. N., Randle, P. J.: Immunoassay of insulin with insulinantibody precipitate. Biochem. J. 88, 137-146 (1963)

13. Schmidt, F. H.: Die enzymatische Bestimmung von Glucose und Fructose nebeneinander. Klin. Wschr. 39, 1244-1247 (1961)

14. Goodner C. J., Conway M. J., Werrbach J. H.: Relation between plasma glucose levels of mother and fetus during maternal hyperglycemia, hypoglycemia and fasting in the rat. Pediat. Res. 3, 121-127 (1969)

15. Gerrard, J. W., Chin, W.: The syndrome of transient diabetes. J. Pediat. 61, 89-93 (1962)

16. Ferguson, A. W., Milner, R. D. G.: Transient neonatal diabetes mellitus in sibs. Arch. Dis. Childh. 45, 80-83 (1970)

17. Sodoyez-Goffaux, F., Sodoyez J.-C.: (Unpublished observation)

18. Frye, B. E.: The differentiation of the endocrine pancreas in fetuses of alloxan diabetic and insulin treated rats. J. Morph. 101, 325-57 (1957)

19. Frerichs, M., Reich, U., Creutzfeldt, W.: Insulinsekretion in vitro I. Hemmung der glucoseinduzierten Insulinabgabe durch Insulin. Klin. Wschr. 43, 136-140 (1965)

20. Sodoyez, J.-C., Sodoyez-Goffaux, F., Foà, P. P.: Evidence for an insulin induced inhibition of insulin release by isolated islets of Langerhans. Proc. Soc. exp. Biol. (N. Y.) 130, 568-571 (1969)

21. Sodoyez, J.-C., Sodoyez-Goffaux, F., Rossen, R. M., Foà P. P.: Function of the pancreatic B-cells in hamsters bearing a transplantable islet cell tumor. Metabolism 18, 433-438 (1969)

22. Liljenquist, J. E., Chiasson, J. L., Jennings, A. S., Horwitz, D. L., Rubenstein, A. H.: Insulin suppression of insulin secretion in man. Demonstration by C-peptide assay. Diabetes 24 (Sup. 2), 403 (1975)

23. Buse, M. G., Robers, W. J., Buse, J.: The role of the human placenta in the transfer and metabolism of insulin. J. clin. Invest. 41, 29-41 (1962)

24. Spellacy, W. N., Goetz, F. C., Greenbert, B. Z., Ells, J.: The human placental gradient for plasma insulin and blood glucose. Amer. J. Obstet. Gynec. 90, 753-757 (1964)

25. Wolf, H., Sabata, V., Frerichs, H., Stubbe, P.: Evidence for the impermeability of the human placenta for insulin. Horm. Metab. Res. 1, 274-275 (1969)

26. Kalhan, S. C., Schwartz, R., Adam, P. A. J.: Placental barrier to human insulin-1 ${ }^{125}$ in insulin-dependent diabetic mothers. J. clin. Endocr. 40, 139-142 (1975)

Received: September 29, 1975, and in revised form: November 20 , 1975

J.-C. Sodoyez, M. D.

Université de Liège

Hôpital de Bavière

Institut de Médecine

Departement de Clinique

et de Pathologie Médicales

B-4000 Liège

Belgium 